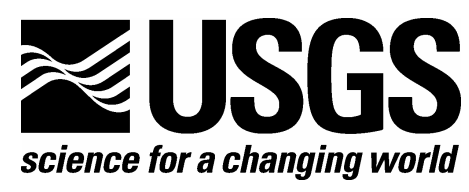

\title{
PUBLICATIONS OF THE WESTERN EARTH SURFACE PROCESSES TEAM 2004
}

Compiled by Charles Powell, II, and Paul Stone

U.S. Geological Survey Open-File Report 2005-1362

U.S. Department of the Interior

U.S. Geological Survey 


\section{U.S. Department of the Interior \\ Gale A. Norton, Secretary}

\section{U.S. Geological Survey \\ P. Patrick Leahy, Acting Director}

U.S. Geological Survey, Reston, Virginia 2005

Revised and reprinted: 2005

For product and ordering information:

World Wide Web: http://www.usgs.gov/pubprod

Telephone: 1-888-ASK-USGS

For more information on the USGS - the Federal source for science about the Earth, its natural and living resources, natural hazards, and the environment:

World Wide Web: http://www.usgs.gov

Telephone: 1-888-ASK-USGS

Suggested citation:

Powell, Charles, II, and Stone, Paul, 2005, Publications of the Western Earth Surface Processes

Team 2004: U.S. Geological Survey Open-File Report 2005-1362, 16 p.

Any use of trade, product, or firm names is for descriptive purposes only and does not imply endorsement by the U.S. Government.

Although this report is in the public domain, permission must be secured from the individual copyright owners to reproduce any copyrighted material contained within this report. 
Contents

INTRODUCTION.

4

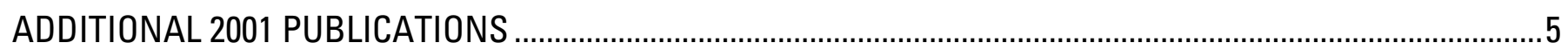

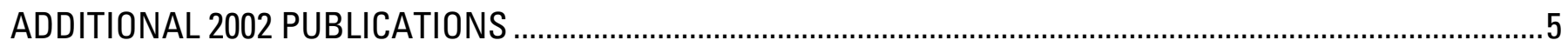

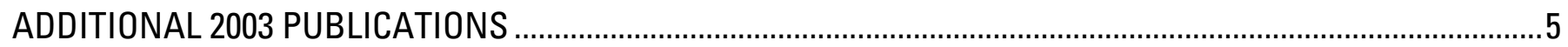

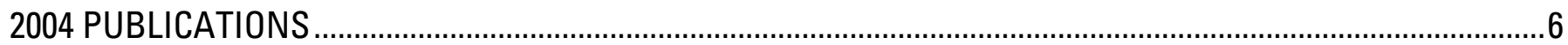




\title{
Publications of the Western Earth Surface Processes Team 2004
}

\author{
Compiled by Charles Powell, II, and Paul Stone) ${ }^{1}$
}

\section{INTRODUCTION}

The Western Earth Surface Processes Team (WESPT) of the U.S. Geological Survey (USGS) conducts geologic mapping, earth-surface processes investigations, and related topical earth science studies in the western United States. This work is focused on areas where modern geologic maps and associated earth-science data are needed to address key societal and environmental issues such as ground-water quality, landslides and other potential geologic hazards, and land-use decisions. Areas of primary emphasis in 2004 included southern California, the San Francisco Bay region, the Mojave Desert, the Colorado Plateau region of northern Arizona, and the Pacific Northwest. The team has its headquarters in Menlo Park, California, and maintains smaller field offices at several other locations in the western United States.

The results of research conducted by the WESPT are released to the public as a variety of databases, maps, text reports, and abstracts, both through the internal publication system of the USGS and in diverse external publications such as scientific journals and books. This report lists publications of the WESPT released in 2004 as well as additional 2001, 2002, and 2003 publications that were not included in the previous lists (USGS Open-File Reports 00-215, 01-198, 02-269, 03-363, 2004-1267). Most of the publications listed were authored or coauthored by WESPT staff. The list also includes some publications authored by non-USGS cooperators with the WESPT, as well as some authored by USGS staff outside the WESPT in cooperation with WESPT projects.

Several of the publications listed are available on the World Wide Web; for these, URL addresses are provided. Many of these web publications are USGS Open-File reports that contain large digital databases of geologic map and related information.

Information on ordering USGS publications can be found on the World Wide Web at http://www.usgs.gov/pubprod/, or by calling 1-888-ASK-USGS. The U.S. Geological Survey’s web server for geologic information in the western United States is located at http://geology.wr.usgs.gov/. More information is available about the WESPT is available on-line at http://geology.wr.usgs.gov/wgmt.

\footnotetext{
${ }^{1}$ Menlo Park, CA 94025
} 


\section{ADDITIONAL 2001 PUBLICATIONS}

Haugerud, R.A., Weaver, C.S., and Harless, J., 2001, Finding faults with LIDAR in the Puget lowland [abs.]: Seismological Research Letters, v. 72, no. 2, p. 253.

Longpré, C.I., 2001, Surficial geology of lower Comb Wash, San Juan County, Utah: U.S. Geological Survey Open-File Report 01-424, scale 1:12,000, 17 p., http://geopubs.wr.usgs.gov/open-file/of01-424/.

\section{ADDITIONAL 2002 PUBLICATIONS}

Jachens, R.C., Sweetkind, D.S., Langenheim, V.E., Phelps, G.A., and McKee, E.H., 2002, Building hydrogeologic framework models of basins-Contributions from geophysically-based elements [abs.]: Geological Society of America Abstracts with Programs, v. 34, no. 6, p. 394.

Moore, T.E., Potter, C.J., and O’Sullivan, P.B., 2002, Superposed coaxial orogens in the Brooks Range fold-and-thrust belt, Alaska [abs.]: Geological Society of America Abstracts with Programs, v. 34, no. 6, p. 77.

\section{ADDITIONAL 2003 PUBLICATIONS}

Brueseke, M.E., Hart, W.K., Wallace, A.R., Heizler, M.T., and Fleck, R.J., 2003, Mid-Miocene volcanic field development in northern Nevada: new age constraints on the timing of Santa Rosa-Calico volcanism [abs.]: Geological Society of America Abstracts with Programs, v. 35, no. 4, p. 63.

Fisher, M.A., Glen, J.M., Ratchkovski, N.A., Pellerin, L.M., and Nokelberg, W.J., 2003, Geophysical investigation of the Denali Fault and Alaska Range Orogen within the aftershock zone of the October-November, 2002, M=7.9 Denali Earthquake [abs.]: Eos, Transactions, American Geophysical Union, v. 84, no. 46, Fall Meeting Supplement, p. F1001, Abstract S12A-0378.

Fisher, M.A., Pellerin, L., Glen, J.M. , Ratchkovski, N.A. , and Nokleberg, W.J., 2003, A Geophysical transect across the Alaska Range-Relationship between crustal structure and the November, 2002, M=7.9 Denali Earthquake [abs.]: Geological Society of America Abstracts with Programs, v. 35, no. 6, p. 561.

Gautier, D.L., 2003, Carboniferous-Rotliegend total petroleum system description and assessment results summary: U.S. Geological Survey Bulletin 2211, 29 p., http://pubs.usgs.gov/bul/b2211.

Glen, J.M.G., 2003, Active crustal dynamics in the bend of the southern Alaska orocline, USA, submitted to the AGU-EGS-EUG Joint Assembly, http://www.cosis.net/members/meetings/sessions/accepted_contributions.php?p_id=49 \&s_id=402.

Hereford, R., 2003, Map showing Quaternary geology and geomorphology of the Lonely Dell Reach of the Paria River, Lees Ferry, Arizona, with comparative landscape photographs, and accompanying pamphlet, Comparative landscape photographs of the Lonely Dell 
area and the mouth of the Paria River, by R. H. Webb and R. Hereford: U.S. Geological Survey Geologic Investigations Series I-2771, scale 1:5,000, http://pubs.usgs.gov/imap/i2771/.

Howell, D.G., and Swinchatt, J.P., 2003, The terroir of the Napa Valley area [abs.]: Geological Society of America Abstracts with Programs, v. 36, no. 5, p. 186.

Huber, N.K., Bateman, P.C., and Wahrhaftig, C., 2003, Geologic map of Yosemite National Park and vicinity, California-A digital database: U.S. Geological Survey Miscellaneous Investigations Series I-1874, scale 1:125,000, http://pubs.usgs.gov/imap/i1874.

Jarboe, N.A., Coe, R.S., Glen, J.M.G., and Renne, P.R., 2003, A study of mid-Miocene Yellowstone hotspot volcanics and the search for the Steens Mountain reversal [abs.]: Eos, Transactions, American Geophysical Union, v. 84, no. 46, Fall Meeting Supplement, p. F530, Abstract GP11C-0276.

Lampe, C., Peters, K.E., Magoon, L.B., Bird, K.J., and Lillis, P.G., 2003, The Shublik’s petroleum systems of the Alaskan North Slope-A numerical journey from source to trap [abs.]: Abstracts, AAPG Annual Meeting, May 11-14, 2003, Salt Lake City, Utah, Search and Discovery Article 90013, http://www.searchanddiscovery.com/documents/abstracts/annual2003/short/77978.pdf.

Moore, T.E., Potter, C.J., O’Sullivan, P.B., Shelton, K.L., and Underwood, M.B., 2003, Association of deformation and fluid events in the central Brooks Range fold and thrust belt, northern Alaska: Abstracts, AAPG Annual Meeting, May 11-14, 2003, Salt Lake City, Utah, Search and Discovery Article 90013, http://www.searchanddiscovery.com/documents/abstracts/annual2003/short/79649.pdf.

Pluhar, C.J., Nomade, S., Glen, J.M.G., and Coe, R.S., 2003, Jaramillo, Cobb Mtn., or Punaruu? - Re-examination of “Cobb Mtn. Event” lavas at the Coso Volcanic Field, CA [abs.]: Eos, Transactions, American Geophysical Union, v. 84, no. 46, Fall Meeting Supplement, p. F548, Abstract GP31D-0774.

Presser, T.S., Piper, D.Z., Bird, K.J., Skorupa, J.P., Hamilton, S.J., Detwiler, S.J., and Huebner, M.A., 2003, The Phosphoria Formation: a model for forecasting global selenium sources to the environment, in Hein, J.R., ed., Life cycle of the Phosphoria Formation: from deposition to post-mining environment: Handbook of Exploration and Environmental Geochemistry, v. 8, p. 299-319.

Schuenemeyer, J.H., 2003, Methodology and results for the assessment of oil and gas resources, National Petroleum Reserve in Alaska: U.S. Geological Survey Open-File Report 03118, 201 p., http://geopubs.wr.usgs.gov/open-file/of03-118.

\section{PUBLICATIONS}

Alvarez, R.M., and others, 2004, Geologic map mosaic of the Long Beach, Los Angeles, Oceanside, San Bernardino, San Diego, and Santa Ana 30’ x 60’ quadrangles, southern California Arial Mapping Project (SCAMP)—A cooperative Statemap Fedmap project [abs.]: Geological Society of America Abstracts with Programs, v. 36, no. 4, p. 93. 
Amoroso, L., Pearthree, P.A., and Arrowsmith, J.R., 2004, Paleoseismology and neotectonics of the Shivwitz section of the Hurricane Fault, northwestern Arizona: Bulletin of the Seismological Society of America, v. 94, no. 5, p. 1919-1942.

Anderson, M., Matti, J.C., and Jachens, R.J., 2004, Structural model of the San Bernardino Basin, California from analysis of gravity, aeromagnetic, and seismicity data: Journal of Geophysical Research, v. 109, no. B4, B04404, p. 1-20.

Bacon, S.N., and Jayko, A.S., 2004, Holocene(?) and latest Pleistocene surface ruptures on the southern Inyo Mountain Fault, southern Owens Valley, Eastern California Shear Zone [abs.]: Geological Society of America Abstracts with Programs, v. 36, no. 4, p. 16.

Barnett, E.A., Weaver, C.S., Meagher, K.L., Wang, Z., Madin, I.P., Wang, M., Haugerud, R.A., Wells, R.E., Ballantyne, D.B., Darienzo, M., and the Southern Willamette Valley Working Group, 2004, Lifelines and earthquake hazards in the Interstate 5 Urban Corridor-Cottage Grove to Woodburn, Oregon: U.S. Geological Survey Open-File Report 2004-1052, http://pubs.usgs.gov/of/2004/1052/.

Bernd, R.T., Simoneit, K.E., Peters, B.G., Rohrback, B.G., Brenner, S., and Kaplin, I.R., 2004, Thermal alteration of Cretaceous black shale from the eastern Atlantic. III. Laboratory simulations, in Hill, R.J., Leventhal, J. Aizenshtat, Z., Baedecker, M.J., Claypool, G., Eganhouse, R., Goldhaber, M., and Peters, K., eds., Geochemical investigations in earth and space science: A tribute to Isaac R. Kaplan, The Geochemical Society Special Publication Series 9, p. 321-340.

Billingsley, G.H., 2001(2004), Important extrusive and intrusive igneous rock units, in Young, R.A., and Spamer, E.E., eds., Colorado River-Origin and evolution: Grand Canyon, Ariz., Grand Canyon Association Monograph 12, p. 223-232.

Billingsley, G.H., Beard, L.S., Priest, S.S., Wellmeyer, J.L., and Block, D.L., 2004, Geologic map of the lower Grand Wash Cliffs and vicinity, Mohave County, northwestern Arizona: U.S. Geological Survey Miscellaneous Field Studies Map MF-2427, scale 1:31,680, 17 p., http://pubs.usgs.gov/mf/2004/2427/.

Billingsley, G.H., Priest, S.S., and Felger, T.J., 2004, Geologic map of Pipe Spring National Monument and the western Kaibab-Paiute Indian Reservation, Mohave County, Arizona: U.S. Geological Survey Scientific Investigations Map 2863, scale 1:31,680, 22 p., http://pubs.usgs.gov/sim/2004/2863/.

Bird, K.J., 2004, Assessment of undiscovered petroleum resources of the North Slope "Middle Ground Area" [abs.]: Anchorage, Alaska Geological Society Newsletter, March, 2004.

Blakely, R.J., Beeson, M.H., Cruikshank, K., Wells, R.E., Johnson, A., and Walsh, K., 2004, Gravity study through the Tualatin Mountains, Oregon-Understanding crustal structure and earthquake hazards in the Portland urban area: Bulletin of the Seismological Society of America, v. 94, p. 1402-1409.

Blakely, R.J., Sherrod, B.L., Wells, R.E., and Weaver, C.S., 2004, Finding active faults in a glaciated and forested landscape-The southern Whidbey Island Fault, Washington [abs.]: Eos, Transactions, American Geophysical Union, v. 85, no. 47, Fall Meeting Supplement, p. F613. 
Blakely, R.J., Sherrod, B.L., Wells, R.E., Weaver, C.S., McCormack, D.H., Troost, K.G., and Haugerud, R.A., 2004, The Cottage Lake aeromagnetic lineament-A possible onshore extension of the southern Whidbey Island Fault, Washington: U.S. Geological Survey Open-File Report 2004-1204, 60 p., http://pubs.usgs.gov/of/2004/1204/.

Booth, D.B., and Waldron, H.H., 2004, Geologic map of the Des Moines 7.5' quadrangle, King County, Washington: U.S. Geological Survey Scientific Investigations Map 2855, scale 1:24,000, http://pubs.usgs.gov/sim/2004/2855/.

Booth, D.B., Waldron, H.H. and Troost, K.G., 2004, Geologic map of the Poverty Bay 7.5' quadrangle, King and Pierce Counties, Washington: U.S. Geological Survey Scientific Investigations Map 2854, scale 1:24,000, http://pubs.usgs.gov/sim/2004/2854/.

Booth, D.B., Wells, R.E., and Givler, R.W., 2004, Chimney damage in the greater Seattle area from the Nisqually Earthquake of 28 February 2001: Bulletin of the Seismological Society of America, v. 94, p. 1143-1158.

Burke, R.M., Redwine, J., Zaprowski, B.J., Bowers, R., and Evenson, E., 2004, Soil chronosequence investigations of knickzone migrations that resulted in fluvial terraces of the Belle Fourche and Cheyenne Rivers, South Dakota [abs.]: Geological Society of America Abstracts with Programs, v. 36, no. 5, p. 499.

Butler, R.F., Ault, C.R., Bishop, E.M., Blakely, R.J., Wells, R.E., and Conrey, R.M., 2004, Teachers on the leading edge-Designing a place-based and field-based teacher professional development program featuring the Pacific Northwest active continental margin [abs.]: Geological Society of America Abstracts with Programs, v. 36, no. 5, p. 555.

Cook, H. E. and Corboy, J. J, 2004, Great basin Paleozoic carbonate platform: facies, facies transitions, depositional models, platform architecture, sequence stratigraphy, and predictive mineral host models: U.S. Geological Survey Open-File Report 2004-1078, 200 p., http://pubs.usgs.gov/of/2004/1078/.

Crews, J.M., Stanley, R.G., Till, A.B., Lillis, P.G., and Simpson, M.K., 2005, Surface thermal maturity of the Yukon Flats region, east-central Alaska [abs.]: Geological Society of America Abstracts with Programs, v. 37, no. 4, p. 95.

Delusina, I., and Redwine, J., 2004, Reconstruction of environmental conditions for pluvial Lake Newark during MIS 2 (Newark Valley, Nevada, USA): 32nd International Geological Congress, Abstract 44-11, http://www.32igc.info/igc32/search/.

Delusina, I., and Redwine, J., 2004, New pollen record from late-glacial/post-glacial transition (MIS 2) for pluvial Lake Newark (Newark Valley, Nevada, USA): XI International Palynological Congress, 4 - 9 July 2004, Grenada, Spain. [only on CD distributed at meeting].

Dudash, S.L., 2004, Quaternary geology of the Calico Mountains piedmont and Coyote Lake, Mojave Desert, California [abs.]: Geological Society of America Abstracts with Programs, v. 36, no. 5, p. 582-583.

Ellen, S.D., de la Fuente, J., Falls, J.N., and McLaughlin, R.J., 2004, Ground and its movement in northwestern California: Program for Redwood region forest science symposium, 
March 15-17, 2004, Rohnert Park, California, http://www.cnr.berkeley.edu/forestry/redwood_paper15-ellen.html [web only].

Evarts, R.C., 2004, Geologic map of the Ariel quadrangle, Clark and Cowlitz Counties, Washington: U.S. Geological Survey Scientific Investigations Map 2826, scale 1:24,000, 35 p., http://pubs.usgs.gov/sim/2004/2826/.

Evarts, R.C., 2004, Geologic map of the Ridgefield quadrangle, Clark and Cowlitz Counties, Washington: U.S. Geological Survey Scientific Investigations Map 2844, scale 1:24,000, 22 p., http://pubs.usgs.gov/sim/2004/2844/.

Evarts, R.C., 2004, Geologic map of the Saint Helens quadrangle, Columbia County, Oregon, and Clark and Cowlitz counties, Washington: U.S. Geological Survey Scientific Investigations Map 2834, scale 1:24,000, 24 p., http://pubs.usgs.gov/sim/2004/2834/.

Evarts, R.C., 2004, Geologic map of the Woodland quadrangle, Clark and Cowlitz Counties, Washington: U.S. Geological Survey Scientific Investigations Map 2827, scale 1:24,000, 38 p., http://pubs.usgs.gov/sim/2004/2827/.

Felger, T.J., Robinson, S.E., Howard, K.A., and Beard, L.S., 2004, Evolution of the course of the Colorado River in Detrital Valley and Boulder Canyon, lower Lake Mead region, Nevada and California [abs.]: Geological Society of America Abstracts with Programs, v. 36, no. 5, p. 514-515.

Fisher, M.A., Nokleberg, W.J., Ratchkovski, N.A., Pellerin, L., Glen, J.M., Brocher, T.M., and Booker, J., 2004, Geophysical investigation of the Denali Fault and Alaska Range orogen within the aftershock zone of the October-November 2002, M=7.9 Denali Fault earthquake: Geology, v. 32, no. 3, p. 269-272.

Fleck, R.J. and Criss, R.E., 2004, Location, age, and tectonic significance of the western Idaho suture zone (WISZ): U.S. Geological Survey Open-File Report 2004-1039, 48 p., http://pubs.usgs.gov/of/2004/1039/.

Glen, J.M.G., 2004, A kinematic model for the southern Alaska orocline based on regional fault patterns, in Sussman, A.J., and Weil, A.B., eds., Orogenic curvature-Integrating paleomagnetic and structural analyses: Geological Society of America Special Paper 383, p. 161-172.

Glen, J.M.G., McKee, E. H. , Ludington, S., Ponce, D.A., Hildenbrand, T.G., and Hopkins, M.J., 2004, Geophysical terrenes of the Great Basin and parts of surrounding provinces: U.S. Geological Survey Open-File Report 2004-1008, 303 p., http://pubs.usgs.gov/of/2004/1008/.

Graymer, R.W., and Pike, R.J., 2004, Geologic maps identify landslide hazards, in Thomas, W.A., ed., Meeting challenges with geologic maps: Alexandria, VA, American Geological Institute, p. 38-39.

Gryc, G., 2004, Petroleum exploration and development on Alaska's North Slope: 1944 To Present: International Conference, Cryosphere of oil-and-gas bearing provinces: Dedicated to the sixtieth anniversary of Tyumen Region, Tyumen, Russia, 22-29 May, 2004, p. 51. 
Hagstrum, J.T., Atwater, B.F., and Sherrod, B.L., 2004, Paleomagnetic correlation of late Holocene earthquakes among estuaries in Washington and Oregon: Geochemistry Geophysics Geosystems, v. 5, no. 10, Q10001, doi:10.1029/2004GC000736, http://www.agu.org/journals/gc/gc0410/2004GC000736/ [web only].

Hanson, K.L., Lettis, W.R., McLaren, M., Savage, W.U., and Hall, N.T., 2004, Style and rate of Quaternary deformation of the Hosgri Fault zone, offshore south-central coastal California: U.S. Geological Survey Bulletin 1995-BB, 37 p., http://pubs.usgs.gov/bul/1995/bb [web only].

Haugerud, R.A., 2004, Cascadia-Physiography: U.S. Geological Survey Geologic Investigations Series I-2689, http://pubs.usgs.gov/imap/i2689/.

Hereford, R., Webb, R.H., and Longpré, C.I., 2004, Precipitation history of the Mojave Desert region, 1893-2001: U.S. Geological Survey Fact Sheet 117-03, http://pubs.usgs.gov/fs/fs117-03/.

Hillhouse, J.W., and Morin, Robert, 2004, Investigation of linear magnetic anomalies in the Funeral Mountains, Death Valley region, California: U.S. Geological Survey Open-File Report 03-12, 16 p., http://pubs.usgs.gov/of/2003/of03-12/.

Hosford Scheirer, A., 2004, Modeling the San Joaquin Basin in three dimensions [abs.]: Abstracts, Pacific Section AAPG, SEPM, and SEG, May 9-12, 2004, Bakersfield, California, USA, Search and Discovery Article 90028, http://www.searchanddiscovery.com/documents/abstracts/2004pacific/hosford01.pdf.

Hosford Scheirer, A., Gautier, D.L., Magoon, L.B., Peters, K.E., and Tennyson, M.E., 2004, Integrated stratigraphic framework for the San Joaquin Basin [abs.]: Abstracts, Pacific Section AAPG, SEPM, and SEG, May 9-12, 2004, Bakersfield, California, USA, Search and Discovery Article 90028, http://www.searchanddiscovery.com/documents/abstracts/2004pacific/hosford02.pdf.

Hosford Scheirer, A., Gautier, D.L., and Tennyson, M.E., 2004, USGS assessment of undiscovered oil and gas resources in the siliceous rocks of the Monterey Formation, central San Joaquin Basin, California [abs.]: Abstracts, Pacific Section AAPG, SEPM, and SEG, May 9-12, 2004, Bakersfield, California, USA, Search and Discovery Article 90028, http://www.searchanddiscovery.com/documents/abstracts/2004pacific/hosford03.pdf.

House, P.K., Howard, K.A., Pearthree, P.A., and Bell, J.W., 2004, Preliminary geologic map of the Nevada and Arizona parts of the Mount Manchester Quadrangle: Nevada Bureau of Mines and Geology Open-File report OF04-4, scale 1:24,000, ftp://comstock.nbmg.unr.edu/pub/dox/dox.htm.

Houseknecht, D.W., and Bird, K.J., 2004, Sequence stratigraphy of the Kingak Shale (Jurassic Lower Cretaceous), National Petroleum Reserve in Alaska: American Association of Petroleum Geologists Bulletin, v. 88, no. 3, p. 279-302.

Howard, K.A., 2004, Lava dams compared in Boise River Canyon and Grand Canyon [abs.]: Geological Society of America Abstracts with Programs, v. 36, no. 4, p. 85. 
Howard, K.A., Barnes, C.B., Snoke, A.W., Wright, J.E., and Lee, S-Y., 2004, Style of intrusion of crustal melts into back-arc middle crust-Ruby Mountains core complex, Nevada [abs.]: Geological Society of America Abstracts with Programs, v. 36, no. 4, p. 71.

Howard, K.A., and Bohannon, R.G., 2001(2004), Lower Colorado River-Upper Cenozoic deposits, incision, and evolution, in Young, R.A., and Spamer, E.E., eds., Colorado River-Origin and evolution: Grand Canyon, Ariz., Grand Canyon Association Monograph 12, p. 101-105.

Howard, K.A., John, B.E., and Foster, D.A., 2004, Unroofing of the Pyrenees - Constraints from combined apatite and zircon fission-track thermochronology [abs.]: 32nd International Geological Congress, Abstract 297-13, http://www.32igc.info/igc32/search/.

Howard, K.A., Lundstrom, S.C., and Matmon, A., 2004, Ancestral Colorado River potholes high above Hoover Dam [abs.]: Geological Society of America Abstracts with Programs, v. 36, no. 5, p. 515.

Howard, K.A., and MacCready, T., 2004, Geologic map of the Verdi Peak Quadrangle, Elko County, Nevada: Nevada Bureau of Mines and Geology Map 147, 4 p., scale 1:24,000.

Huber, N.K., 2004, A tale of two valleys: Yosemite, v. 66, no. 4, p. 6-9.

Jachens, R.C., and Griscom, A., 2004, Geophysical and geologic setting of the earthquake, inferred from gravity and magnetic anomalies, in Wells, R.E., ed., The Loma Prieta, California, Earthquake of October 17, 1989-Geologic setting and crustal structure: U.S. Geological Survey Professional Paper 1550-E, p. E49-E80, http://pubs.usgs.gov/pp/pp1550e.

Jayko, A.S., 2004, Plio-Pleistocene extension of a late Miocene-early Pliocene erosion surface in the southern Inyo, Argus And Coso Ranges, Eastern California Shear Zone [abs.]: Geological Society of America Abstracts with Programs, v. 36, no. 4, p. 17.

Jayko, A.S., 2004, Comparison of the Plio-Pleistocene and Quaternary transtensive deformation structures along the Pacific-North American Plate boundary, Eastern Sierra region, southwestern Inyo County, California [abs.]: Eos, Transactions, American Geophysical Union, v. 85, no. 47, Fall Meeting supplement, p. F567, Abstract G11A-0782.

Langenheim, V.E., 2004, Gravity and magnetic anomalies of Santa Catalina Island and vicinity, southern California, in Legg, M., Davis, P., and Gath, E., eds., Geology and tectonics of Santa Catalina Island and the California Continental Borderland: South Coast Geological Society Guidebook 32, p. 277-290.

Langenheim, V.E., Jachens, R.C., Hildenbrand, T.G., Anderson, M.L., Lee, T., Morton, D.M., and Matti, J.C., 2004, Deep secrets of faults, blocks, and basins revealed by gravity, magnetic, and geologic data in southern California [abs.]: Geological Society of America Abstracts with Programs, v. 36, no. 5, p. 318.

Langenheim, V.E., Jachens, R.C., Morton, D.M., Kistler, R.W., and Matti, J.C., 2004, Geophysical and isotopic mapping of pre-existing crustal structures that influenced the location and development of the San Jacinto Fault zone, southern California: Geological Society of America Bulletin, v. 116, no. 9/10, pp. 1143-1157. 
Langenheim, V.E., McPhee, D.K., Morin, R.L., Blakely, R.J., and Wells, R.E., 2004, A threedimensional view of the Tualatin and northern Willamette basins, Oregon, from inversion of new gravity data [abs.]: Eos, Transactions, American Geophysical Union, v. 85, v. 47, Fall Meeting Supplement, p. F1718.

Lanphere, M.A., Champion, D.E., Clynne, M.A., Lowenstern, J.B., Sarna-Wojcicki, A.M., and Wooden, J.L., 2004, Age of the Rockland tephra, western USA: Quaternary Research, v. 62 , no. 1 , p. 94-104.

Lettis, W.R., Hanson, K.L., Unruh, J.R., McLaren, M., and Savage, W.U., 2004, Quaternary tectonic setting of south-central coastal California: U.S. Geological Survey Bulletin 1995-AA, 24 p., http://pubs.usgs.gov/bul/1995/aa [web only].

Lucchitta, I., McDougall, K., Metzger, D.G., Morgan, P., Smith, G.R., and Chernoff, B., 2001 (2004), The Bouse Formation and Post-Miocene uplift of the Colorado Plateau, in Young, R.A. and Spanner, E.E., eds., Colorado River-Origins and Evolution: Grand Canyon, Ariz., Grand Canyon Association Monograph 12, p. 167-172.

Magoon, L.B., Lillis, P.G., Peters, K.E., Hosford Scheirer, A., Lampe, C., and Gautier, D.L., 2004, Four petroleum systems in the San Joaquin Basin, California [abs.]: Abstracts, Pacific Section AAPG, SEPM, and SEG, May 9-12, 2004, Bakersfield, California, USA, Search and Discovery Article 90028, http://www.searchanddiscovery.com/documents/abstracts/2004pacific/magoon.pdf.

Magoon, L.B., Peters, K.E., Hosford Scheirer, A., Lampe, C., Gautier, D.L., and Lillis, P.G., 2004, Modeling petroleum systems in the San Joaquin Basin, California [abs.]:

Abstracts, AAPG annual meeting, April 18-21, 2004, Dallas, Texas, Search and Discovery Article 90026, http://www.searchanddiscovery.com/documents/abstracts/annual2004/Dallas/Magoon.ht m.

Mankinen, E.A., Hildenbrand, T.G., Zientek, M.L., Box, S.E., Bookstrom, A.A., Carlson, M.H., and Larsen, J.C., 2004, Guide to geophysical data for the northern Rocky Mountains and adjacent areas, Idaho, Montana, Washington, Oregon, and Wyoming: U.S. Geological Survey Open-File Report 2004-1413, 34 p., http://pubs.usgs.gov/of/2004/1413/.

Mankinen, E.A., and Wentworth, C.M., 2004, Mono Lake excursion recorded in sediment of the Santa Clara Valley, California: Geochemistry Geophysics Geosystems, v. 5, no. 2, Q02H05, doi:10.1029/2003GC000592, http://www.agu.org/journals/gc/gc0402/2003GC000592/ [web only].

McCabe, C.A., McPhee, D.K., Valin, Z.C., McLaughlin, R.J., Jachens, R.C., Langenheim, V.E., and Wentworth, C.M., 2004, Preliminary 3-dimensional geologic map of the Santa Rosa plain, northern California [abs.]: Eos, Transactions, American Geophysical Union, v. 85, no. 47, Fall Meeting Supplement, p. F1618.

McCulloh, T.H., and Beyer, L.A., 2004, Mid-Tertiary isopach and lithofacies maps for the Los Angeles region, California-Templates for palinspastic reconstructions to $17.4 \mathrm{Ma}$ : U.S. Geological Survey Professional Paper 1690, 38 p., http://pubs.usgs.gov/pp/pp1690.

McLaughlin, R.J., and Clark, J.C., 2004, Stratigraphy and structure across the San Andreas Fault zone in the Loma Prieta region and deformation during the earthquake, in Wells, 
R.E., ed., The Loma Prieta, California, earthquake of October 17, 1989—Geologic setting and crustal structure: U.S. Geological Survey Professional Paper 1550-E, p. E5E47, http://pubs.usgs.gov/pp/pp1550e.

McLaughlin, R.J., Sarna-Wojcicki, A.M., Fleck, R.J., Wright, W.H., Levin, V.R.G., and Valin, Z.C., 2004, Geology, tephrochronology, radiometric ages, and cross sections of the Mark West Springs 7.5' quadrangle, Sonoma and Napa Counties, California: U.S. Geological Survey Scientific Investigations Map 2858, scale 1:24,000, 16 p., http://pubs.usgs.gov/sim/2004/2858/.

McPhee, D.K., Jachens, R.C., and Wentworth, C.M., 2004, Crustal structure across the San Andreas Fault at the SAFOD site from potential field and geologic studies: Geophysical Research Letters, v. 31, no. 12, L12503, doi:10.1029/2003GL019363, 4 p.

McPhee, D.K., Tilden, J., Jachens, R.C., and Wentworth, C.M., 2004, Crustal structure across the San Andreas Fault at the SAFOD site, California, from gravity and magnetic studies [abs.]: Eos, Transactions, American Geophysical Union, v. 85, no. 47, Fall Meeting Supplement, p. F1627.

Miller, F.K., 2004, Preliminary geologic map of the Big Bear City 7.5' Quadrangle, San Bernardino County, California: U.S. Geological Survey Open File Report 2004-1193, scale 1:24,000, http://pubs.usgs.gov/of/2004/1193/.

Miller, F.K., and Burmester, R.F., 2004, Geologic map of the Bonners Ferry 30' x 60' quadrangle, Idaho and Montana. U.S. Geological Survey Miscellaneous Field Studies Map MF-2426, scale 1:100,000, 28 p., http://geopubs.wr.usgs.gov/map-mf/mf2426/.

Molnia, B., 2004, Glossary of glacier terminology—A glossary providing the vocabulary necessary to understand the modern glacier environment: U.S. Geological Survey Open-File Report 2004-1216, http://pubs.usgs.gov/of/2004/1216/.

Morton, D.M., 2004, Preliminary geologic map of the Santa Ana 30' x 60' quadrangle, southern California, version 2.1: U.S. Geological Survey Open-File Report 99-172 (version 2.1), scale 1:100,000, 46 p., http://pubs.usgs.gov/of/1999/of99-172/.

Morton, D.M., Alvarez, R.M., and Campbell, R.H., 2004, Development of soil slip susceptibility maps for soil slips generated during winter rains, southwestern California [abs.]: Geological Society of America Abstracts with Programs, v. 36, no. 4, p. 93.

Morton, D.M., and Kennedy, M.P., 2004, Detailed and regional geologic maps produced by the Southern California Arial Mapping Project [abs.]: Geological Society of America Abstracts with Programs, v. 36, no. 5, p. 581.

Nazarova, K.A., and Glen, J.M., 2004, Integration of NASA/GSFC and USGS Rock Magnetic Databases [abs.]: Eos, Transactions, American Geophysical Union, v. 85, no.17, Joint Assembly Supplement, p. JA164, Abstract GP21A-04.

Norman, L.M., Webb, R.H., Gass, L., Yanites, B., Howard, K., Pfeifer, E., and Beard, L.S., 2004, Geospatial analysis of changes in river-channel position and riparian vegetation of the lower Colorado River: Geological Society of America Abstracts with Programs, v. 36, no. 5, p. 515. 
Peters, K.E., Bird, K.J., Magoon, L.B., Lampe, C., Lillis, P.G., and Verma, M.K., 2004, Modeling petroleum systems on the North Slope of Alaska [abs.]: Abstracts, AAPG Annual Meeting, April 18-21, 2004, Dallas, Texas, Search and Discovery Article 90026, http://www.searchanddiscovery.com/documents/abstracts/annual2004/Dallas/Peters.htm

Peters, K.E., Magoon, L.B., Hosford Scheirer, A., Lampe, C., Gautier, D.L., and Lillis, P.G., 2004, A 3D petroleum system model for the San Joaquin Basin, California [abs.]: Abstracts, Pacific Section AAPG, SEPM, and SEG, May 9-12, 2004, Bakersfield, California, USA, Search and Discovery Article 90028, http://www.searchanddiscovery.com/documents/abstracts/2004pacific/peters.pdf.

Phelps, G.A., Jachens, R.C., Moring, B.C., and Roberts, C.W., 2004, Modeling of the Climax Stock and related plutons based on the inversion of magnetic data, southwest Nevada: U.S. Geological Survey Open-File Report 2004-1345, 21 p., http://pubs.usgs.gov/of/2004/1345/.

Pike, R.J., 2004, Digital elevation model, in Goudie, Andrew, ed., The IAG Encyclopedia of geomorphology: London, Routledge, v. 1 (of 2), p. 260-263.

Plenier, G.D., and Glen, J.M.G., 2004, Complex magnetic fabrics in igneous rocks [abs.]: Eos, Transactions, American Geophysical Union, v. 85, no. 47, Fall Meeting Supplement, p. F655.

Ponce, D.A., Graymer, R.W., Jachens, R.C., Simpson, R.W., Phelps, G.A., and Wentworth, C.M., 2004, Three-dimensional geology of the Hayward Fault and its correlation with fault behavior, northern California [abs.]: Eos, Transactions, American Geophysical Union, v. 85, no. 47, Fall Meeting Supplement, p. F1397.

Ponce, D.A., Simpson, R.W., Graymer, R.W, and Jachens, R.C., 2004, Gravity, magnetic, and high precision relocated seismicity profiles suggest a connection between the Hayward and Calaveras Faults, northern California: Geochemistry Geophysics Geosystems, v. 5, no. 7, Q07004, doi:10.1029/2003GC000684, 39 p., http://www.agu.org/journals/gc/gc0407/2003GC000684/ [web only].

Powell, C.L., II, 2004, Using zoogeographic correlations of marine invertebrate faunas to date late Tertiary and Quaternary deposits [abs.]: 2004 Southern California Earthquake Council meeting (Palm Springs, Calif., September 19-23, 2004), Proceedings and Abstracts, v. XIV, p. 145-146.

Powell, C.L., II, Allen, J.R., and Holland, P.J., 2004, Invertebrate paleontology of the Wilson Grove Formation (late Miocene to late Pliocene), Sonoma and Marin Counties, California, with some observations of its stratigraphy, thickness, and structure: U.S. Geological Survey Open-File Report 2004-1017, 106 p., http://pubs.usgs.gov/of/2004/1017/.

Powell, C.L., II, Stone, P., and Graymer, R.W., 2004, Publications of the Western Earth Surfaces Processes Team 2003: U.S. Geological Survey Open-File Report 2004-1267, 18 p., http://pubs.usgs.gov/of/2004/1267/.

Redwine, J., and Reheis, M., 2004, A modified history of Lakes Manix and Mojave, California [abs.]: Geological Society of America Abstracts with Programs, v. 36, no. 5, p. 498. 
Reid, M.E., Brien, D.L., Ellen, S.D., de la Fuente, J., Falls, J.N., and Hicks, D.B., 2004, Comparison of topographic models for debris slide locations [abs.]: http://www.cnr.berkeley.edu/forestry/redwood_paper16-reid.html [web only].

Roberts, C.W., Jachens, R.C., Ponce, D.A., and Langenheim, V.E., 2004, Isostatic residual gravity map of the Santa Clara Valley and vicinity, California: U.S. Geological Survey Open-File Report 2004-1297, scale 1:100,000, http://pubs.usgs.gov/of/2004/1297/.

Sable, E.G., and Hereford, Richard, 2004, Geologic map of the Kanab 30’ X 60’ quadrangle, Utah and Arizona: U.S. Geological Survey Geologic Investigations Series I-2655, scale 1:100,000, http://pubs.usgs.gov/imap/2655/.

Sarna-Wojcicki, A.M., 2004, Past and future directions of North Pacific tephrochronology [abs.]: Eos, Transactions, American Geophysical Union, v. 85, no. 47, Fall Meeting Supplement, p. F1835.

Sarna-Wojcicki, A.M., Slate, J.L., Wan, E., and Walker, J.P., 2004, A chronostratigraphic reference set of tephra layers from the Jemez Mountains volcanic source, New Mexico [abs.], in Hudson, M., ed., Geologic and hydrogeologic framework of the Española Basin-Proceedings of the 3rd annual Española Basin workshop, Santa Fe, New Mexico, March 2-3, 2004: U.S. Geological Survey Open-File Report 2004-1093, p. 28, http://pubs.usgs.gov/of/2004/1093/.

Schmidt, K.M., Nimmo, J., Miller, D., Stock, J., Winfield, K., Perkins, K., and Belknap, S., 2004, Quaternary geology, unsaturated soil-moisture measurements, and evidence for overland flow in the Globe piedmont, Mojave Desert, CA [abs.]: Eos, Transactions, American Geophysical Union, v. 85, no. 47, Fall Meeting Supplement, p. F803-F804.

Simpson, R.W., Graymer, R.W., Jachens, R.C., Ponce, D.A., and Wentworth, C.M., 2004, Cross-section and maps showing double-difference relocated earthquakes from 19842000 along the Hayward and Calaveras Faults, California: U.S. Geological Survey Open-File Report 2004-1083, http://pubs.usgs.gov/of/2004/1083/.

Stanley, R.G., Ahlbrandt, T.S., Charpentier, R.R., Cook, T.A., Crews, J.M., Klett, T.R., Lillis, P.G., Morin, R.L., Phillips, J.D., Pollastro, R.M., Rowan, E.L., Saltus, R.W., Schenk, C.J., Simpson, M.K., Till, A.B., and Troutman, S.M., 2004, Oil and gas assessment of Yukon Flats, east-central Alaska, 2004: U.S. Geological Survey Fact Sheet 2004-3121, 2 p., http://pubs.usgs.gov/fs/2004/3121/.

Stock, J.D., Schmidt, K.M., and Miller, D.M., 2004, Observations on alluvial fans with relevance to recent sediment transport [abs.]: Eos, Transactions, American Geophysical Union, v. 85, no. 47, Fall Meeting Supplement, p. F854.

Stoffer, P.W., 2004, Desert landforms and surface processes in the Mojave National Preserve and vicinity: U.S. Geological Survey Open-File Report 2004-1007, 20 p., http://pubs.usgs.gov/of/2004/1007/.

Stoffer, Philip W., 2004, Geology of the San Andreas Fault in the Santa Cruz Mountains: SEPM (Society of Sedimentary Geology) Pacific Section Fall Field Trip Guidebook (October 9-10, 2004, Saratoga, California), 75 p.

Stone, P., Dunne, G.C., Conrad, J.E., Swanson, B.J., Stevens, C.H., and Valin, Z.C., 2004, Geologic map of the Cerro Gordo Peak 7.5’ quadrangle, Inyo County, California: U.S. 
Geological Survey Scientific Investigations Map 2851, scale 1:24,000, 17 p., http://pubs.usgs.gov/sim/2004/2851/.

Sweetkind, D.S., Langenheim, V.E., Rytuba, J.J., McLaughlin, R.J., Wagner, D., and Farrar, C.D., 2004, Geologic and geophysical mapping of the Sonoma volcanic field, California-A progress report on hydrogeologic applications in the Napa and Sonoma basins [abs.]: Geological Society of America Abstracts with Programs, v. 36, no. 5, p. 579.

Tabor, R.W., Haugerud, R.A., Hildreth, W., and Brown, E.W., 2004, Geologic map of the Mount Baker 30- by 60-minute quadrangle, Washington: U.S. Geological Survey Geologic Investigations Series I-2660, 73 p., http://pubs.usgs.gov/imap/i2660/.

Tauxe, L., Gans, P., and Mankinen, E.A., 2004, Paleomagnetism and 40-Ar/39-Ar ages from volcanics extruded during the Matuyama and Brunhes Chrons near McMurdo Sound, Antarctica: Geochemistry Geophysics Geosystems, v. 5, no. 6, Q06H12, doi:10.1029/2003GC000656, http://www.agu.org/journals/gc/gc0406/2003GC000656/ [web only].

Tilden, J.E., Greene, H.G., and Blakely, R.J., 2004, Marine geology of the southwestern San Juan Islands-New insights from multibeam imagery and processed aereomagnetic data: Eos, Transactions, American Geophysical Union, v. 85, no. 47, Fall Meeting Supplement, p. F1058.

Todd, V.R., compiler, 2004, Preliminary geologic map of the El Cajon 30’ x 60’ quadrangle, southern California: U.S. Geological Survey Open-File Report 2004-1361, scale 1:100,000, 31 p., http://pubs.usgs.gov/of/2004/1361/.

Toro, F., Toro, J., Bird, K., and Harrison, C., 2004, The Arctic Alaska-Canada connection revisited [abs.]: Geological Society of America Abstracts with Programs, v. 36, no. 5, p. 22.

Troutman, S.M., and Stanley, R.G., 2004, Maps showing sedimentary basins, surface thermal maturity, and indications of petroleum in the Central Alaska Province: U.S. Geological Survey Miscellaneous Field Studies Map MF-2428, scale 1:2,500,000, 20 p., http://geopubs.wr.usgs.gov/map-mf/mf2428/.

Vermeij, G.J., and Powell, C.L., II, 2004, Nucella megastoma, a new late Pliocene Muricid gastropod from northern California: Proceedings of the California Academy of Sciences, v. 55, no. 9, p. 184-189.

Verosub, K., Davis, J.O., and Sarna-Wojcicki, A.M., 2004, Pleistocene lacustrine sediments in the Lake Tahoe Basin, California [abs.]: Geological Society of America Abstracts with Programs, v. 36, no. 5, p. 499.

Walker, J.P., Wan, E., and Sarna-Wojcicki, A.M., 2004, Uses of geochemical and geochronological databases developed in the U.S. Geological Survey Tephrochronology Laboratory, Menlo Park, CA [abs.]: Geological Society of America Abstracts with Programs, v. 36, no. 4, p. 11.

Wells, R.E., 2004, Introduction, in Wells, R.E., ed., The Loma Prieta, California, earthquake of October 17, 1989—Geologic setting and crustal structure: U.S. Geological Survey Professional Paper 1550-E, p. E1-E4, http://pubs.usgs.gov/pp/pp1550e. 
Wells, R.E., Blakely, R.J., Sugiyama, Y., Scholl, D.S., and Dinteman, P., 2004, Basin-centered asperities in great subduction zone earthquakes-Is there a link to subduction erosion? [abs.]: 32nd International Geological Congress, Abstract 298-4, http://www.32igc.info/igc32/search/.

Webb, R.H., McCabe, G.J., Hereford, R., and Wilkowske, C., 2004, Climatic fluctuations, drought, and flow in the Colorado River: U.S. Geological Survey Fact Sheet 3062-04, 4 p., http://pubs.usgs.gov/fs/2004/3062/.

Yerkes, R.F., and Campbell, R.H., 2004, Preliminary digital geologic map of the Los Angeles 30’ x 60’ quadrangle, southern California [abs.]: Geological Society of America Abstracts with Programs, v. 36, no. 5, p. 580. 